\title{
IMPACT OF ORGANIC AND INORGANIC NUTRIENT MANAGEMENT ON YIELD IN RICE UNDER SUGARCANE BASED CROPPING SYSTEM IN CALCIORTHANTS
}

\author{
U. N. UMESH ${ }^{1}$, VIPIN KUMAR ${ }^{2}$, KUMARI VIBHA RANI ${ }^{1}$, A.P.SINGH ${ }^{2} \&$ K. D. N. SINGH ${ }^{2}$ \\ ${ }^{1}$ Krishi Vigyan Kendra, Harnaut, Nalanda, Bihar, India \\ ${ }^{2}$ DRPCAU, Pusa, Bihar, India
}

\begin{abstract}
Experiment was conducted on new area farm of Samastipur district to study the effect of integrated nutrient management in rice-sugarcane-sugarcane ratoon-1-sugarcane ratoon-II - moong cropping system on seed production of rice. There is significant increase in yields of grain and straw by increasing the levels of nitrogen alone or in combination with different organics from 2.54 to 3.70 ton per hectare and 4.01 to 6.03 ton per hectare respectively. The maximum increase in yield of grain and straw of rice was recorded with the application of recommended dose of NPK along with green manuring. The combined application of organic and inorganic fertilizers gives better result as compared to sole application of inorganic fertilizer. Nutrients uptake by rice was also recorded highest under $100 \%$ NPK + green manure as moong treatment. The nutrients status of soil was improved at higher level of nitrogen and the effect was more noticeable when nitrogen was applied in conjoint with organic manure.
\end{abstract}

KEYWORDS: Rice, Seed Yield, Biogas Slurry, Sulphitated Pressmud, Sugarcane Trash

Received: Oct 07, 2020; Accepted: Oct 27, 2020; Published: Dec 12, 2020; Paper Id.: IJASROCT20208

\section{INTRODUCTION}

The production of rice is adversely affected by regular application of high dose of chemical fertilizers. It leads to degradation of soil day by day and the yield of rice is severely affected. As per findings of Nambiar and Abrol (1989) the productivity of rice is declining by application of recommended dose of N, P and K. For maintain soil health as well as sustainable production of rice the high cost chemical fertilizers are substituted by low cost locally available organic manures like bio compost, vermicompost, sulphitated pressmud, green manures, nadep compost, etc in integrated manners as per findings of Acharya (2002). Nitrogen is one of the most important nutrients for cultivation of rice in major soils of India. Integrated nutrient management along with balanced supply of nutrients are essential factor for sustainable crop production system in future .We can do judicious application of inorganic nitrogen along with organic sources. As per findings of Singh et al (2001) the application of organic and inorganic fertilizer in proper proportion enhances the crop growth maintains the organic carbon level in soil and productivity of crop also improves. Therefore, the experiment is done to maintain the sustainable production of rice and uptake of different nutrients by plants as well as soil chemical properties.

\section{MATERIALS AND METHODS}

A part of long-term field experiment was conducted at New Area Farm of Sugarcane Research Institute, RAU, Pusa, Samastipur, Bihar on Rice-Sugarcane plant-Sugarcane ratoon-1-Sugarcane ratoon-2-Moong rotation. The surface soil of the farm have following properties such as $\mathrm{pH}\left(1: 2\right.$, soil:water) 8.2, electrical conductivity $0.20 \mathrm{dS} \mathrm{m}^{-1}$, Free $\mathrm{CaCO}_{3}$ 27.5\%, Organic carbon $4.96 \mathrm{~g} \mathrm{~kg}^{-1}$, Available $\mathrm{N}$ was $227 \mathrm{~kg}$ per ha, Available $\mathrm{P}_{2} \mathrm{O}_{5} 26.4 \mathrm{~kg}$ per ha, Available $\mathrm{K}_{2} \mathrm{O} 95.0$ 
$\mathrm{kg}$ per ha and DTPA extractable $\mathrm{Zn} 0.65 \mathrm{mg}$ per $\mathrm{kg}$ initially. The climatic condition of experimental site was sub-tropical humid. The maximum temperature was $36.1{ }^{\circ} \mathrm{C}$, minimum was $7.6{ }^{\circ} \mathrm{C}$ and mean annual temperature was $24.5{ }^{\circ} \mathrm{C}$ during January. The mean annual precipitation during May to October was $1200 \mathrm{~mm}$. The soil texture of experimental site is sandy loam. This experiment consists of eight treatments with four replications. The trial is conducted in randomized block design with plot size of $25 \mathrm{~m} \times 9 \mathrm{~m}$. After harvest of ( $\left.17^{\text {th }} \mathrm{crop}\right)$ sugarcane the soil samples are collected from plots. The different treatments that were used in experiments are $\mathrm{T}_{1}-\mathrm{N}_{50} \mathrm{P}_{100} \mathrm{~K}_{100}, \mathrm{~T}_{2}-\mathrm{N}_{100} \mathrm{P}_{100} \mathrm{~K}_{100}, \mathrm{~T}_{3}-\mathrm{T}_{1}+20 \mathrm{t}$ per ha biogas slurry, $\mathrm{T}_{4}-\mathrm{T}_{2}+20 \mathrm{t}$ per ha biogas slurry, $T_{5}-T_{1}+$ green manure (Moong), $T_{6}-T_{2}+$ green manure (Moong), $T_{7^{-}} T_{1}+10 t$ per ha sugarcane trash + $10 \mathrm{t}$ per ha sulphitated pressmud and $\mathrm{T}_{8}-\mathrm{T}_{2}+10 \mathrm{t}$ per ha sugarcane trash $+10 \mathrm{t}$ per ha sulphitated pressmud. Treatment $\mathrm{N}_{100}$, $\mathrm{P}_{100}, \mathrm{~K}_{100}$ means $150 \mathrm{~kg}$ of $\mathrm{N}$ in the form of urea, $37.5 \mathrm{~kg}$ of $\mathrm{P}$ in the form of single super phosphate and $50 \mathrm{~kg}$ of potash in the form of muriate of potash. Nitrogen was applied in different split doses, half of total amount at the time of planting, one fourth of rest amount at the time of first irrigation and at the time of earthing up, one fourth of rest amount is applied with the commencement of monsoon. Whole amount of phosphorus and potash were applied before the time of planting. The crop residues and trash was cut in to small pieces and incorporated in soil after wetting with water at proper moisture level.

Observation on plant height, yield attributes, seed quality attributed like 100 seed weight, seed length, seed width, etc. were recorded in randomly selected seeds in each replication following the ISTA rules (Anonymous, 1999). After harvesting the yields of straw and grain of rice were recorded. The composite soil samples from different plots were collected after harvest of rice crop and samples were analysed for organic carbon by Walkley and Black, 1934 method, available nitrogen by Subbiah and Asija, 1956 method, available phosphorous by Olsen's et al, 1954 method, ammonium acetate extractable potassium by Jackson, 1973 method, available Zinc by Lindsay and Norvell, 1978 and total nitrogen, phosphorus, potash, zinc, and sulphur contents were analysed form the plant samples by Jackson, 1973 method.

\section{RESULTS AND DISCUSSION}

By combined application of different organic and inorganic fertilizers the yield of paddy, nutrient uptake by plants is improved. Although physical, chemical and biological property of soil is also improved as compared to inorganic fertilizer application in rice sugarcane based cropping system.

\section{Effect on Different Yield Attributes}

We got significant result on different yield attributes like productive tillers hill ${ }^{-1}$, plant height, and panicle length by applying different treatments as compared to control. However, seed length, seed width and 1000 seed weight did not increase significantly. The maximum enhancement in yield attributes were recorded $100 \%$ NPK with green manure. Thus, application of adequate nutrients at higher NPK level or applied through integrated nutrient management promoted the supply of assimilates from the sources to sink would have resulted in production of higher number of bold grains per panicle as per findings of Singh and Mandal, 1997 and Singh et al, 2010.

The influence of integrated application of organic and inorganic fertilizers on rice crop under sugarcane based cropping system the yield of straw and grain varied from 2.54 to $3.70 \mathrm{t}$ per ha and 4.9 to $6.03 \mathrm{t}$ per ha as per findings in (Table 1). The significant increase in yield of grain and straw with increased dose of nitrogen alone or along with different types of organic manures. The highest yield of grain (3.70 ton per hectare) and straw (6.03 ton per hectare) was recorded in case of $\mathrm{T}_{6}$ where, $100 \%$ NPK was applied along with green manuring with green gram while lowest yield of grain (2.54 ton per hectare) and straw (4.01 ton per hectare) was found in treatment $\mathrm{T}_{1}\left(\mathrm{~N}_{50} \mathrm{P}_{100} \mathrm{~K}_{100}\right)$. The result of application of organic 
manure in combination with inorganic fertilizers was found better as compared to inorganic fertilizer alone (Swarup and Yaduvanshi, 2000; Singh et al., 2010). As per findings of Mehedi et al., (2011) application of 75\% recommended dose of fertilizer along with organic fertilizer gives better yield as compared to conventional system. Similar result was also found by Yadav et al., (2019) in case of integrated use of fertilizers in paddy cultivation. Mahmud et al., (2016) also reported that excessive use of chemical fertilizer reduces the yield of rice in contrast with integrated application enhances the production. The increase in yield of grain and straw by application of $50 \%$ fertilizer through organic source is reported by Sharada and Sujathamma, (2018).

\section{Influence of INM on Different Types of Nutrient Absorption by Plants}

The uptake of nitrogen, phosphorus and potassium varied from 45.6 to $73.3,9.4$ to $16.1,76.5$ to $127.8 \mathrm{~kg}$ per hectare, respectively (Table 2). The highest nitrogen, phosphorus and potassium uptakes were obtained at treatment $\mathrm{T}_{6}$, where, $100 \%$ NPK along with green manuring was applied. The lowest uptake of nitrogen, phosphorus and potassium were recorded in the treatment $\mathrm{T}_{1}$ where $50 \% \mathrm{~N}$ was applied along with $100 \% \mathrm{P}$ through single super phosphate and $100 \% \mathrm{~K}$ through muriate of potash alone. The effectiveness of organic matter is increasing $\mathrm{N}, \mathrm{P}$ and $\mathrm{K}$ uptakes by rice were in the order: green manure > SPM + ST > BGS (Dixit and Gupta, 2000). The sulphur uptake varied from 5.15 to $9.09 \mathrm{~kg}$ per hectare and zinc uptake varied from 161 to $315 \mathrm{~g}$ per hectare respectively. Application of $100 \% \mathrm{~N}$ singly or in combination with organic manures was always found superior over $50 \% \mathrm{~N}$. The maximum sulphur-uptake by rice $\left(9.09 \mathrm{~kg}\right.$ per ha) was recorded in the treatment $\mathrm{T}_{8}(100 \%$ $\mathrm{NPK}+10 \mathrm{t} \mathrm{ST}+10 \mathrm{t}$ SPM per hectare) which is at par with treatment $\mathrm{T}_{6}(100 \% \mathrm{NPK}+$ green manure). The effect of BGS was found non-significant (Rakesh, 1999). The highest $\mathrm{Zn}$ uptake by rice was obtained at treatment $\mathrm{T}_{6}$, where $100 \% \mathrm{NPK}+$ GM and at par with $\mathrm{T}_{4}(100 \% \mathrm{NPK}+\mathrm{BGS})$ and $\mathrm{T}_{8}(100 \% \mathrm{NPK}+10 \mathrm{t} \mathrm{ST}+10 \mathrm{t}$ SPM $)$ treatment. The lowest Zn uptake by rice was found in treatment $\mathrm{T}_{1}$, where $50 \%$ of $\mathrm{N}$ applied along with $100 \% \mathrm{PK}$ through inorganic fertilizers. The improvement in $\mathrm{Zn}$-uptake by application of chemical fertilizers along with organic source of manures was also recorded by several workers (Singh et al. 1998; Prasad et al. 2010 and Kumar and Singh, 2010).As per findings of Chinnamani et al., (2018) Increase in nutrient uptake by integrated use of organic source of nutrient along with chemical fertilizer.

\section{Effect of Inorganic and Organic Source of Nutrients on Various Soil Properties}

The various combinations of treatments had given significant result on changes in organic carbon content in soil as per (Table 3). The improvement in level of soil organic carbon by sole application of inorganic fertilizer $\mathrm{N}$ or in addition with sulphitated press mud + sugarcane trash, biogas slurry and green manuring due to incorporation of organic matter. The highest organic carbon accumulation was observed in plot where sulphitated press mud and sugarcane trash were applied. As per findings of Singh et al, 2005 by integrated use of organic and inorganic nitrogen increase in level of organic carbon content without reducing in yield leads to sustainable production system. Availability of $\mathrm{N}, \mathrm{P}$ and $\mathrm{K}$ content in soil after completion of $3^{\text {rd }}$ cycle of rotation varied from 201 to $233,26.8$ to 36.4 and 104 to $119 \mathrm{~kg}$ per hectare, respectively due to different types of treatment combinations as per findings in (Table 3 ). The highest N, P and $\mathrm{K}$ contents were obtained in treatment $\mathrm{T}_{6}$, where 100 $\%$ NPK was added along with green manuring with green gram. The effect of organic manure were more significant as compared to sole application of N, P and K, however, all the sources of organic manure were found equally effective except direct influence of green manuring. The effectiveness of organic in improving $\mathrm{N}, \mathrm{P}$ and $\mathrm{K}$ status of soil at both $\mathrm{N}$ levels was found in the order: green manuring > SPM + ST > BGS (Tolanur and Badanur, 2003). The available S and Zn contents in soil increased by application of $100 \%$ of NPK + organic sources as compared to inorganic fertilizer. Available sulphur varied from 8.9 to $15.4 \mathrm{mg}$ per $\mathrm{kg}$ with maximum value of $15.4 \mathrm{mg}$ per $\mathrm{kg}$ in treatment $\mathrm{T}_{8}$, where, $100 \% \mathrm{NPK}$ along with $\mathrm{SPM}$ and 
sugarcane trash were applied. When higher level of $\mathrm{N}$ was applied as inorganic fertilizer only did not improve available $\mathrm{S}$ status of soil however, applied with any organic manure, the improvement in available $\mathrm{S}$ at higher $\mathrm{N}$ level was significant (Singh et al, 1999). The availability of zinc content ranged from 0.63 to $0.85 \mathrm{mg}$ per $\mathrm{kg}$ under different treatment combinations (Table 3). The highest zinc content $\left(0.85 \mathrm{mg}\right.$ per $\mathrm{kg}$ ) in soil was recorded in treatment $\mathrm{T}_{8}$, where $100 \% \mathrm{NPK}$ along with SPM and sugarcane trash were applied. The effect of SPM + ST was significant over green manuring and the zinc status reached above the critical limit i.e. $0.78 \mathrm{mg}$ per $\mathrm{kg}$ as per findings of Sakal et al. (1996).As per findings of Tharmaraj et al., (2011) the improvement in physical and chemical properties of soil by application of different source of organic nutrients. Increase in bacterial count by use of different organic source of nutrients was also reported by Kumari et al., (2017).

\section{CONCLUSIONS}

It is concluded from the said experiment that integrated nutrient management augmented and sustained the level of soil fertility as well as crop productivity. It holds a great promising in preventing various types of nutrient deficiencies symptoms and also maintains soil health from deterioration.

\section{REFERENCES}

1. Acharya, C. L., 2002. Integrated input management for sustainable crop production in rainfed agro-ecosystem. Journal of the Indian Society of Soil Science. 50: 45-51.

2. Anonymous 1999. International rules for seed testing. Seed Sci. and Technol. $27: 1-333$.

3. Chinnamani, N., Kumar, A., Hemalatha, M. And Suresh, S. 2018. Influence of integrated nutrient management practices on yield and nutrient uptake of rice under system of rice intensification. Int. J. Adv. Agri. Sci. Tech. 2(1):54-61.

4. Jackson ML 1973. Soil chemical analysis. Prentice Hall of India Pvt. Ltd., New Delhi

5. Kumari, R., Kumar, S., Kumar, R., Das, A., Kumari, R., Choudhary, C.D., Sharma, R.P.2017. Effect of long term integrated nutrient management on crop yield, nutrition and soil fertility under rice-wheat system. J.Appl.Nat.Sci.9:1801-1807.

6. Kumar Vipin and Singh AP 2010. Long term effect of green manuring and farm yard manure on yield and soil fertility status in rice-wheat cropping system. J. Indian Society of Soil Science 58 (4) : 409-412.

7. Lindsay WL and Norvell WA 1978. Development of DTPA soil test for zinc, iron, manganese and copper. Soil Science Society America J. 42 : 421-428.

8. Mahmud, A.J., Shamsuddoha, A.T.M., Haque, M.N.2016.Effect of organic and inorganic fertilizer on the growth and yield of rice (Oryza sativa L.). Nat Sci.14(2):45-54.

9. Mehdi, S.M., Sarfraz, M., Abbas, S.T. and Shabbir,G.2011. Integrated nutrient management for rice-wheat cropping system in a recently reclaimed soil. Soil Environ.30(1):36-44.

10. Nambiar KKM and Abrol I.P. 1989. Long term fertilizer experiment in Indian over view. Fertilizer News 34:11-20 and 26.

11. Olsen SR, Coles CV, Watanabe PS and Dean LN 1954. Estimation of available Phosphorus in soil by Extraction with sodium bicarbonate, USDA Circular, 939.

12. Prasad RK, Kumar Vipin, Prasad B and Singh AP 2010. Long term effect of crop residues and zinc fertilizer on crop yield, nutrient uptake and fertility build-up under rice-wheat cropping system in calciorthents. J. Indian Society of Soil Science 58 (2) : 205-211. 
13. Rakesh AP 1999. Reaction of organic manure amended sulphur in calcareous soil in relation to sulphur nutrition of crops. Ph.D. Thesis, RAU, Pusa, Bihar.

14. Sakal R, Singh AP, Sinha RB and Bhogal NS 1996. Twenty five year of Research on Micro and Secondary Nutrient in Soils and crops of Bihar, Research Bulletin, Department of Soil Science, R.A.U., Pusa, Samastipur, Bihar

15. Sharada, P., Sujathamma,P.2018. Effect of organic and inorganic fertilizers on the quantitative and qualitative parameters of rice (Oryza sativa L.) Curr.Agri.Res.6(2).doi: http://dx.doi.org/10.12944/CARJ.6.2.05.

16. Singh M, Singh VP and Sammi Reddy K. 2001. Effect of integrated use of fertilizer nitrogen and farmyard manure or green manure on transformation of $N, K$, and $S$ and productivity of rice-wheat system on a vertisol. J. Indian Society of Soil Science 49 : 430-435.

17. Singh NP, Sachan RS, Pandey PC and Bisht PS 1999. Effect of a decade long fertilizer and manure application on soil fertility and productivity of rice-wheat system in amollisol. Journal of the Indian Society of Soil Science 47 (1) : 72-80.

18. Singh YV and Mandal BK 1997. Nutrient of rice (Oryza sativa) through Azolla, organic materials and urea. Indian J. Agronomy $42(4): 626-633$

19. Singh YV, Singh KK, Sharma and SK, Meena DS 2010. Effect of integrated nutrient management on yield and seed quality in rice. Oryza $47(3): 215-220$.

20. Subbiah BV and Asijia GL 1956. A rapid procedure for the determination of available nitrogen in soils. Curr. Sci. 25:259-60.

21. Swarup A and Yaduvanshi NPS 2000. Effect of integrated nutrient management on soil properties and yield of rice in alkaline soil. Journal of the Indian Society of Soil Science 48 : 279-282.

22. Tolanur SL and Badanur VP (2003) Effect of integrated use of organic manure, green manure and fertilizer nitrogen on sustaining productivity of rabi sorghum-chickpea system and fertility of vertisol. Journal of Indian Society of Soil Science 51 (1) : 41-44.

23. Walkey A and Black JA 1934. Estimation of soil organic carbon by the chromic acid titration method. Soil Sci. 37: 29-38.

\section{TABLES}

Table 1: Effect of Long Term Integrated Use of Fertilizers and Organics on Yield and Yield Response of Rice under Rice-Sugarcane Based Cropping System in Calciorthants

\begin{tabular}{|c|c|c|c|c|c|c|c|c|c|c|}
\hline Treatments & $\begin{array}{c}\text { Total } \\
\text { Tiller hill- } \\
1\end{array}$ & $\begin{array}{l}\text { Productive } \\
\text { Tiller hill }^{-1}\end{array}$ & $\begin{array}{c}\text { Plant } \\
\text { Height } \\
\text { (cm) }\end{array}$ & $\begin{array}{c}\text { Penicle } \\
\text { Length } \\
\text { (cm) }\end{array}$ & $\begin{array}{c}\text { Filled } \\
\text { Grain } \\
\text { Panicle }\end{array}$ & $\begin{array}{c}\text { Seed } \\
\text { Length }\end{array}$ & $\begin{array}{l}\text { Seed } \\
\text { width }\end{array}$ & $\begin{array}{c}1000 \\
\text { Seed } \\
\text { Weight }\end{array}$ & $\begin{array}{c}\text { Grain } \\
\text { Yield } \\
\left(\mathrm{q} \mathrm{ha}^{-1}\right)\end{array}$ & $\begin{array}{l}\text { Straw Yield } \\
\left(\mathbf{q} \mathbf{h a}^{-1}\right)\end{array}$ \\
\hline $\mathrm{T}_{1} \mathrm{~N}_{50} \mathrm{P}_{100} \mathrm{~K}_{100}$ & 15.0 & 13.0 & 102.0 & 19.1 & 76.0 & 9.2 & 2.2 & 21.5 & 25.4 & 40.1 \\
\hline $\mathrm{T}_{2} \mathrm{~N}_{100} \mathrm{P}_{100} \mathrm{~K}_{100}$ & 16.0 & 14.5 & 105.0 & 19.5 & 82.0 & 9.5 & 2.2 & 22.0 & 29.3 & 45.9 \\
\hline $\begin{array}{l}\mathrm{T}_{3} \mathrm{~N}_{50} \mathrm{P}_{100} \mathrm{~K}_{100}+ \\
20 \mathrm{t} \mathrm{BGS}\end{array}$ & 16.5 & 16.0 & 105.3 & 19.6 & 78.7 & 9.2 & 2.2 & 22.3 & 31.1 & 49.3 \\
\hline $\begin{array}{l}\mathrm{T}_{4} \mathrm{~N}_{100} \mathrm{P}_{100} \mathrm{~K}_{100}+ \\
20 \mathrm{t} \mathrm{BGS}\end{array}$ & 17.0 & 15.5 & 106.7 & 21.2 & 85.3 & 9.8 & 2.3 & 22.5 & 35.1 & 56.4 \\
\hline $\begin{array}{l}\mathrm{T}_{5} \mathrm{~N}_{50} \mathrm{P}_{100} \mathrm{~K}_{100}+ \\
\mathrm{GM} \text { (Moong) }\end{array}$ & 19.0 & 19.3 & 105.0 & 20.0 & 80.0 & 9.5 & 2.2 & 22.1 & 34.0 & 56.1 \\
\hline $\begin{array}{l}\mathrm{T}_{6} \mathrm{~N}_{100} \mathrm{P}_{100} \mathrm{~K}_{100}+ \\
\mathrm{GM} \text { (Moong) }\end{array}$ & 21.0 & 18.4 & 110.0 & 21.9 & 90.0 & 9.9 & 2.3 & 22.4 & 37.0 & 60.3 \\
\hline $\begin{array}{l}\mathrm{T}_{7} \mathrm{~N}_{50} \mathrm{P}_{100} \mathrm{~K}_{100}+ \\
10 \mathrm{t} \mathrm{ST}+10 \mathrm{t} \text { SPM }\end{array}$ & 18.0 & 17.0 & 106.0 & 20.1 & 82.0 & 9.4 & 2.2 & 21.8 & 32.9 & 52.0 \\
\hline $\begin{array}{l}\mathrm{T}_{8} \mathrm{~N}_{100} \mathrm{P}_{100} \mathrm{~K}_{100}+ \\
10 \mathrm{t} \mathrm{ST}+10 \mathrm{t} \mathrm{SPM}\end{array}$ & 19.0 & 17.0 & 108.0 & 21.1 & 88.0 & 9.6 & 2.2 & 22.6 & 36.9 & 55.1 \\
\hline SEm \pm & 0.9 & 0.8 & 5.9 & 0.9 & 3.6 & 0.43 & 0.14 & 1.17 & 1.1 & 1.5 \\
\hline C.D. $(\mathrm{P}=0.05)$ & 2.7 & 2.5 & NS & NS & 10.8 & $\mathrm{NS}$ & $\mathrm{NS}$ & $\mathrm{NS}$ & 3.2 & 4.4 \\
\hline
\end{tabular}

Note : Values in parentheses indicate increase in yield over the treatment $\mathrm{T}_{1}$. 
Table 2: Effect of Long Term Integrated use of Organic and Inorganic Fertilizers on uptake by Rice Under Rice-Sugarcane Based Cropping System in Calciorthants

\begin{tabular}{|c|c|c|c|c|c|}
\hline \multirow[b]{2}{*}{ Treatments } & \multicolumn{5}{|c|}{ Nutrients Uptake } \\
\hline & $\begin{array}{l}\text { Uptake of } \\
\text { nitrogen } \\
\left(\mathrm{kg} \mathrm{ha}^{-1}\right)\end{array}$ & $\begin{array}{c}\text { Uptake of } \\
\text { phosphorous } \\
\left(\mathrm{kg} \mathrm{ha}^{-1}\right)\end{array}$ & $\begin{array}{c}\text { Uptake of } \\
\text { potash } \\
\left(\mathrm{kg} \mathrm{ha}^{-1}\right)\end{array}$ & $\begin{array}{l}\text { Uptake of } \\
\text { sulphur } \\
\left(\mathrm{kg} \mathrm{ha}^{-1}\right)\end{array}$ & $\begin{array}{l}\text { Uptake of zinc } \\
\quad\left(\mathrm{g} \mathrm{ha}^{-1}\right)\end{array}$ \\
\hline $\mathrm{T}_{1} \mathrm{~N}_{50} \mathrm{P}_{100} \mathrm{~K}_{100}$ & 45.6 & 9.4 & 76.5 & 5.15 & 161 \\
\hline $\mathrm{T}_{2} \mathrm{~N}_{100} \mathrm{P}_{100} \mathrm{~K}_{100}$ & 55.0 & 11.2 & 89.0 & 6.20 & 204 \\
\hline $\mathrm{T}_{3} \mathrm{~N}_{50} \mathrm{P}_{100} \mathrm{~K}_{100}+20 \mathrm{t} \mathrm{BGS}$ & 59.4 & 12.0 & 99.7 & 6.66 & 214 \\
\hline $\mathrm{T}_{4} \mathrm{~N}_{100} \mathrm{P}_{100} \mathrm{~K}_{100}+20 \mathrm{t} \mathrm{BGS}$ & 69.1 & 14.7 & 115.7 & 8.35 & 304 \\
\hline $\mathrm{T}_{5} \mathrm{~N}_{50} \mathrm{P}_{100} \mathrm{~K}_{100}+\mathrm{GM}$ (Moong) & 65.4 & 14.0 & 113.3 & 7.47 & 264 \\
\hline $\mathrm{T}_{6} \mathrm{~N}_{100} \mathrm{P}_{100} \mathrm{~K}_{100}+\mathrm{GM}$ (Moong) & 73.3 & 16.1 & 127.8 & 8.91 & 315 \\
\hline $\mathrm{T}_{7} \mathrm{~N}_{50} \mathrm{P}_{100} \mathrm{~K}_{100}+10 \mathrm{t} \mathrm{ST}+10 \mathrm{t} \mathrm{SPM}$ & 62.7 & 12.9 & 105.6 & 7.64 & 237 \\
\hline $\mathrm{T}_{8} \mathrm{~N}_{100} \mathrm{P}_{100} \mathrm{~K}_{100}+10 \mathrm{t} \mathrm{ST}+10 \mathrm{t} \mathrm{SPM}$ & 70.4 & 15.2 & 116.2 & 9.09 & 288 \\
\hline $\mathrm{SEm} \pm$ & 2.4 & 0.4 & 2.6 & 0.13 & 7 \\
\hline C.D. $(\mathrm{P}=0.05)$ & 7.0 & 1.2 & 7.7 & 0.38 & 19 \\
\hline
\end{tabular}

Table 3: Effect of Long Term Integrated use of Organic and Inorganic Fertilizers on Available Nutrients in Soil Under Rice-Sugarcane Based Cropping System in Calciorthants

\begin{tabular}{|c|c|c|c|c|c|c|c|}
\hline \multirow[b]{2}{*}{ Treatments } & \multirow{2}{*}{$\begin{array}{c}\text { Organic } \\
\text { Carbon } \\
\left(\mathrm{g} \mathrm{kg}^{-1}\right)\end{array}$} & \multirow{2}{*}{$\begin{array}{c}\text { Free } \\
\mathrm{CaCO}_{3}(\mathrm{~g} \\
\left.\mathrm{kg}^{-1}\right)\end{array}$} & \multicolumn{5}{|c|}{ Availability of Nutrients } \\
\hline & & & $\begin{array}{c}\mathrm{N} \\
\left(\mathrm{kg} \mathrm{ha}^{-1}\right)\end{array}$ & $\begin{array}{c}\mathrm{P}_{2} \mathrm{O}_{5} \\
\left(\mathrm{~kg} \mathrm{ha}^{-1}\right)\end{array}$ & $\begin{array}{c}\mathrm{K}_{2} \mathrm{O} \\
\left(\mathrm{kg} \mathrm{ha}^{-1}\right)\end{array}$ & $\begin{array}{c}\mathrm{S} \\
\left(\mathrm{mg} \mathrm{kg}^{-1}\right)\end{array}$ & $\begin{array}{l}\mathrm{Zn} \\
\left(\mathrm{mg} \mathrm{kg}^{-1}\right)\end{array}$ \\
\hline $\mathrm{T}_{1} \mathrm{~N}_{50} \mathrm{P}_{100} \mathrm{~K}_{100}$ & 4.80 & 281 & 201 & 26.8 & 104 & 8.9 & 0.63 \\
\hline $\mathrm{T}_{2} \mathrm{~N}_{100} \mathrm{P}_{100} \mathrm{~K}_{100}$ & 4.91 & 280 & 216 & 28.1 & 107 & 10.0 & 0.65 \\
\hline $\mathrm{T}_{3} \mathrm{~N}_{50} \mathrm{P}_{100} \mathrm{~K}_{100}+20 \mathrm{t} \mathrm{BGS}$ & 5.11 & 279 & 213 & 31.1 & 109 & 11.2 & 0.74 \\
\hline $\mathrm{T}_{4} \mathrm{~N}_{100} \mathrm{P}_{100} \mathrm{~K}_{100}+20 \mathrm{t} \mathrm{BGS}$ & 5.25 & 278 & 224 & 33.2 & 112 & 13.3 & 0.80 \\
\hline $\mathrm{T}_{5} \mathrm{~N}_{50} \mathrm{P}_{100} \mathrm{~K}_{100}+\mathrm{GM}$ (Moong) & 5.08 & 279 & 219 & 33.3 & 115 & 10.3 & 0.69 \\
\hline $\mathrm{T}_{6} \mathrm{~N}_{100} \mathrm{P}_{100} \mathrm{~K}_{100}+\mathrm{GM}$ (Moong) & 5.21 & 278 & 233 & 37.5 & 119 & 12.0 & 0.78 \\
\hline $\mathrm{T}_{7} \mathrm{~N}_{50} \mathrm{P}_{100} \mathrm{~K}_{100}+10 \mathrm{t} \mathrm{ST}+10 \mathrm{t} \mathrm{SPM}$ & 5.16 & 278 & 215 & 34.8 & 111 & 13.8 & 0.77 \\
\hline $\mathrm{T}_{8} \mathrm{~N}_{100} \mathrm{P}_{100} \mathrm{~K}_{100}+10 \mathrm{t} \mathrm{ST}+10 \mathrm{t} \mathrm{SPM}$ & 5.36 & 277 & 227 & 36.4 & 117 & 15.4 & 0.85 \\
\hline $\begin{array}{l}\text { SEm } \pm \\
\text { C.D. }(P=0.05)\end{array}$ & $\begin{array}{l}0.03 \\
0.08\end{array}$ & $\begin{array}{c}2 \\
\mathrm{NS}\end{array}$ & $\begin{array}{l}3 \\
8\end{array}$ & $\begin{array}{l}1.2 \\
3.5\end{array}$ & $\begin{array}{l}2 \\
5\end{array}$ & $\begin{array}{l}0.4 \\
1.1\end{array}$ & $\begin{array}{l}0.02 \\
0.06\end{array}$ \\
\hline
\end{tabular}

